\title{
Physicochemical Characteristics of Harvested Rainwater under different Rooftops in Ikole Local Government Area, Ekiti State, Nigeria
}

\author{
*11ADEYEYE, JA; ${ }^{2}$ AKINTAN, OB; ${ }^{1}$ ADEDOKUN, T
}

\author{
${ }^{I}$ Department of Water Resources Management and Agro-meteorology, Federal University Oye-Ekiti, Ekiti State, Nigeria \\ ${ }^{2}$ Department of Geography and Planning Sciences, Faculty of Social Sciences, Ekiti State University, Ekiti State, Nigeria \\ *Corresponding Author Email: joseph.adeyeye@fuoye.edu.ng
}

\begin{abstract}
Due to scarcity of potable water in most rural and urban settings in Ekiti State, rainwater harvesting from rooftop has been favoured as an alternative source of water supply. This study investigated the physicochemical characteristics of rainwater harvested from four different rooftop sheets in Ikole-Ekiti and its environs. Samples were collected three times from the month of June to August, 2018. Parameters investigated include $\mathrm{pH}$, Total Dissolved Solid (TDS), Turbidity, Electrical Conductivity (EC), Alkalinity, Total Hardness, $\mathrm{Ca}^{2+}, \mathrm{Mg}^{2+}, \mathrm{Na}^{+}, \mathrm{K}^{+}, \mathrm{Fe}, \mathrm{Pb}, \mathrm{Zn}, \mathrm{Al}$, and $\mathrm{Cu}$. Data obtained were subjected to descriptive statistics to determine the mean and standard deviation and water quality index measured. The result shows that the physicochemical parameters ranges from 8.03-9.17 (pH), 0.47-3.17 NTU (Turbidity), $56.20-170.43 \mu \mathrm{s} / \mathrm{cm}$ (EC), 30.2-50.53 mg/L (TDS), $18.56-27.58 \mathrm{mg} / \mathrm{L}$ (Alkalinity), $19.94-24.08 \mathrm{mg} / \mathrm{L}$ (Total Hardness), 8.67-14.93mg/L $\left(\mathrm{SO}_{4}{ }^{2+}\right), 4.11-11.67 \mathrm{mg} / \mathrm{L}\left(\mathrm{Cl}^{-}\right), 0-4.62 \mathrm{mg} / \mathrm{L}\left(\mathrm{Zn}^{2+}\right), 7.11-11.13 \mathrm{mg} / \mathrm{L}$ (Calcium), 0.07-1.56 $\mathrm{mg} / \mathrm{L}\left(\mathrm{Al}^{2+}\right), 0.01-0.02 \mathrm{mg} / \mathrm{L}\left(\mathrm{Cu}^{2+}\right), 9.41-21.33 \mathrm{mg} / \mathrm{L}\left(\mathrm{Mg}^{2+}\right), 29.04-40.35 \mathrm{mg} / \mathrm{L}\left(\mathrm{Na}^{2+}\right)$ and $\left(\mathrm{Fe}^{2+}\right)$ 0.1-0.29 $\mathrm{mg} / \mathrm{L}$. Most of the measured parameters were all within permissible water quality standard as recommended by World Health Organizations (WHO) except for the slightly basic character of the rainwater. All measured parameters were high in aluminum sheets and coated rooftops but did not exceed the World Health Organization permissible limit followed by Galvanized zinc rooftop and Panted rooftop. Water Quality Index (WQI) for painted rooftop, aluminum rooftop, galvanized zinc rooftop, and coated rooftop were $3.296,1.335,6.078$ and 2.629 respectively indicating excellent water quality. The study found that harvested rainwater in the area could be used for domestic purpose with minimum treatment to enhance drinkability.
\end{abstract}

\section{DOI: https://dx.doi.org/10.4314/jasem.v23i11.15}

Copyright: Copyright (C) 2019 Adeyeye et al. This is an open access article distributed under the Creative Commons Attribution License (CCL), which permits unrestricted use, distribution, and reproduction in any medium, provided the original work is properly cited.

Dates: Received: 07 October 2019; Revised: 11 November 2019; 24 November 2019

Keywords: Rainwater, Rooftop, Quality, Health and Permissible limit

Water is essential for life. The importance cut across agriculture, domestic, industrial, recreation and tourism. In addition to direct human consumption of water, it is integrally linked to the provision and quality of ecosystems service. In most urban areas, population is increasing rapidly and the issue of supplying adequate water to meet societal needs and to ensure equity in access to water is one of the most urgent and significant challenges faced by decisionmakers. Individuals drill their own shallow or deep wells (boreholes) based on affordability in an attempt to bring water to the table (Ukpong et al., 2013). Among the various alternative technologies to augment freshwater resources, rainwater harvesting and utilization is a decentralized, environmentally sound solution, which can avoid many environmental problems often caused in conventional large-scale projects using centralized approaches. Rainwater harvesting remained a viable source of potable water for rural communities where there are no watery networks. Even in some areas where potable water is supplied by networks, harvested rainwater is still a significant supplemental resource for domestic supply especially during season when low quantity of water is available. Moreover, rainwater harvesting promotes self-sufficiency and encourages water and energy conservation, adaptation to climate change among others (Retamal and Turner, 2010). In the past and up to the moment, some believed that rainwater is pure and could be consumed without pre-treatments. Though this assertion might be true in some locations that are relatively unpolluted, however rainwater collected in many locations contains impurities. Particularly during the last three decades, "acid rain" among others has affected the quality of the collected rainwater due to anthropogenic emission to the point where it now usually requires treatment. Over the years, due to people's inability to find good water in their location coupled with lack of water supply by water agencies, they have engaged in harvesting rainwater for different uses with minimal consideration for the quality. The quality of rainwater harvested could be affected by many factors. These include; the nature of the catchment system, the

*Corresponding Author Email: joseph.adeyeye@fuoye.edu.ng 
presence of particles, and environmental pollution from industries, automobiles and anthropogenic activities. Rainwater sometimes contains some heavy metals (contaminants) which can cause adverse effect on human beings, animals, plants, and surface water. A great percentage of metals fall through the rain at the place of their production. Apart from contamination from atmosphere, roofs are made of variety of materials, and most of these inbuilt are potentially toxic materials which are not suitable as rainwater catchments surfaces. Observed is that different coating or materials with high resistance to corrosion are used. The typical roofing materials that are commonly used in Nigeria today are ceramic tiles, metal sheets, galvanized iron, anodized aluminum and asbestos. All these materials are a potentially source of dissolved ions, alkalinity and trace metals (Ayenimo et al., 2006). Moreover, heavy metals emitted into the atmosphere do form aerosols which are mainly from human activities and are washed away as wet or dry deposition causing damages to surface waters and living organisms. The concern that trace elements in drinking water presents potential health hazard if they are present in higher than recommended concentrations prompted several regulatory bodies like WHO to establish maximum allowable concentrations for these elements in drinking water supplies. Though there are guidelines to application of these roofing materials but the manufacturers often compromised.
Ikole Local Government Area is one of the sixteen local government areas in Ekiti State, Nigeria. Though the State is blessed with abundance water resources, availability of potable water has been a major concern since creation. While the economically viable people could harness borehole water where they are fortunate to reach economic water bearing aquifers, others have resorted to hand-dug wells and rainwater harvesting both for drinking and other domestic uses with less concerns for the quality. In this study, we want to ascertain the physicochemical qualities of the harvested rainwater in the area and suggest possible way forward in order to safeguard the public health.

\section{MATERIAL AND METHODS}

Study Area: The study area is located between $0774916 \mathrm{mE} ; \quad 0862100 \mathrm{mN}$ and $0775141 \mathrm{mE}$; $0862297 \mathrm{mN}$ (Fig. 1). The general geology of Ekiti State has been well researched (Bayowa et al., 2014; Oyinloye, 2011; and Talabi, 2013). The State is underlain by the Precambrian rocks of the basement complex of southwestern Nigeria which covers about $50 \%$ of the land surface of Nigeria (Oladapo and Ayeni, 2013). Major climate seasons in the area are wet and dry seasons while the former is from April to October; the latter is from November to March.

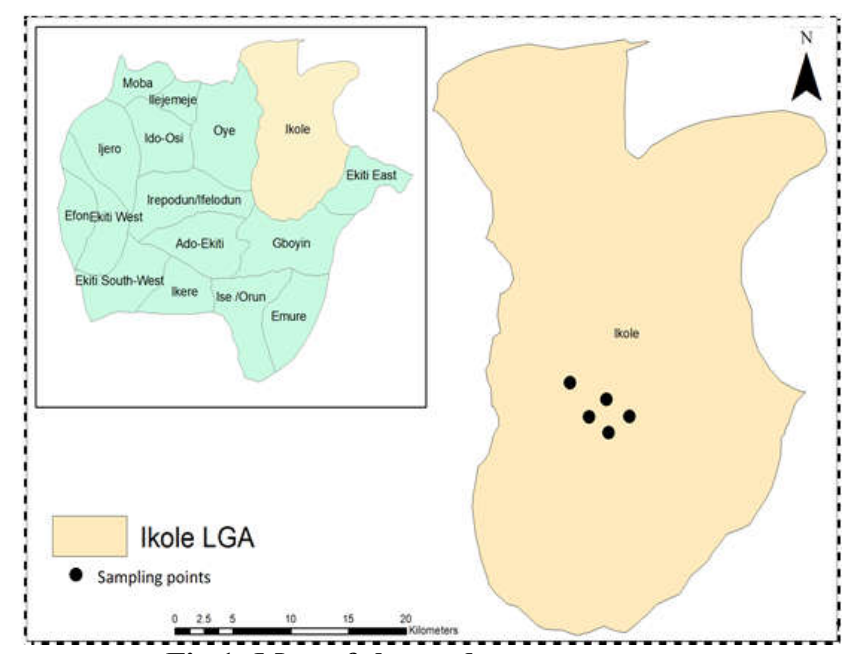

Fig.1: Map of the study area

Sampling Procedure: Rainwater samples were collected from five locations with three replicates from each of the four different types of roofing sheet/materials (Galvanized zinc) roofing sheets, Coated pan, Painted pan and Aluminum sheet) and the control which was harvested in an open field without contact with any catchment roofing surface making the fifth samples.

Water Analysis: Rainwater samples were collected using appropriate techniques and were kept in preclean sample bottles. Samples were placed in cooler boxes with ice chests and transported to the laboratory 
kept at about $4^{\circ} \mathrm{C}$ until they were analyzed. All chemical analyses were done at least in triplicates. Non conservable parameters such as $\mathrm{pH}$, temperature and electrical conductivity were determined in-situ. The $\mathrm{pH}$ was measured with a $\mathrm{pH}$ meter previously calibrated with buffer solution with the temperature reading while conductivity was measured with a conductivity meter calibrated with potassium chloride solution. Other physicochemical properties analyzed include colour, odour, turbidity, total dissolved solids, alkalinity, total hardness, magnesium, sodium, chloride, carbonate, bicarbonate and sulphate following standard procedures as outlined in ALPHA (1999). Samples for trace/heavy metal (zinc, iron, calcium, lead, copper and aluminum) analyses were preserved with $3 \mathrm{ml}$ concentration of $\mathrm{HNO}_{3}$. The presence of heavy metals was conducted using an Atomic Absorption Spectrophotometer (AAS, Buck Scientific 210 VGP).

Quality Assurance Procedure: Special precautions that were considered for quality assurance includes: all reagents used were of standard analytical grade and sample for metal analyses were preserved with $3 \mathrm{ml}$ concentrated $\mathrm{HNO}_{3}$ per litre from the field. Samples for sulphate were refrigerated and analyzed within 24 hours. All plastics and wares used were pre-washed with detergent water solution, rinsed with tap water, soaked for overnight in $50 \% \mathrm{HNO}_{3}$ solution and thoroughly rinsed with distilled water.

Data Analysis: Data obtained were subjected to descriptive statistics to estimate the average, range and standard deviation. Water quality index was also determined using arithmetic weighted method which gives a numerical value to express the overall quality of water. Calculation of WQI was carried out using Horton's method. The WQI is calculated by using equation as reported by Qureshimatva et al. (2015).

\section{RESULTS AND DISCUSSION}

Physicochemical Trends of the Rainwater Samples: The physicochemical characteristics of the rainwater samples harvested and assessed are illustrated in Table I. The results indicated that the physical parameters such as colour, odour, and taste of the analyzed samples were unobjectionable.

Table 1: Physicochemical characteristics of the harvested rainwater samples

\begin{tabular}{|c|c|c|c|c|c|c|}
\hline Parameters & $\begin{array}{l}\text { Painted pan } \\
\text { rooftop }\end{array}$ & $\begin{array}{l}\text { Aluminum } \\
\text { rooftops }\end{array}$ & $\begin{array}{l}\text { Galvanized } \\
\text { zinc rooftops }\end{array}$ & $\begin{array}{l}\text { Coated pan } \\
\text { rooftop }\end{array}$ & Control & $\begin{array}{l}\text { WHO } \\
\text { Limits }\end{array}$ \\
\hline $\mathrm{pH}$ & $8.03 \pm 0.06$ & $9.17 \pm 0.115$ & $8.67 \pm 0.06$ & $8.87 \pm 0.15$ & $8.57 \pm 0.06$ & $6.5-8.5$ \\
\hline Turbidity(NTU) & $0.47 \pm 0.06$ & $0.57 \pm 0.06$ & $3.17 \pm 4.53$ & $0.53 \pm 0.06$ & $0.47 \pm 0.06$ & $5 \mathrm{NTU}$ \\
\hline Electrical conductivity & $87.30 \pm 0.27$ & $100.07 \pm 1.90$ & $56.20 \pm 0.36$ & $170.43 \pm 0.57$ & $76.40 \pm 0.69$ & 500 \\
\hline TDS (mg/L) & $33.77 \pm 1.12$ & $36.40 \pm 0.44$ & $30.20 \pm 1.04$ & $50.53 \pm 0.50$ & $33.07 \pm 1.02$ & 50 \\
\hline Alkalinity (mg/L) & $21.30 \pm 1.59$ & $26.34 \pm 1.451$ & $21.54 \pm 1.98$ & $27.58 \pm 5.50$ & $18.56 \pm 2.07$ & 100 \\
\hline Total Hardness $(\mathrm{mg} / \mathrm{L})$ & $22.39 \pm 0.32$ & $21.88 \pm 5.811$ & $22.15 \pm 5.58$ & $24.08 \pm 5.97$ & $22.39 \pm 0.32$ & 100 \\
\hline Calcium $(\mathrm{mg} / \mathrm{L})$ & $9.90 \pm 0.12$ & $11.13 \pm 0.11$ & $9.71 \pm 0.02$ & $10.33 \pm 0.01$ & $7.11 \pm 0.01$ & 7.5 \\
\hline $\operatorname{Magnesium}(\mathrm{mg} / \mathrm{L})$ & $11.92 \pm 0.61$ & $10.69 \pm 1.37$ & $21.33 \pm 0.02$ & $11.89 \pm 0.01$ & $9.41 \pm 0.61$ & 3.0 \\
\hline $\operatorname{Sodium}(\mathrm{mg} / \mathrm{L})$ & $40.35 \pm 1.17$ & $39.97 \pm 1.03$ & $34.66 \pm 1.57$ & $31.07 \pm 0.79$ & $29.04 \pm 0.97$ & 200 \\
\hline Chloride(mg/L) & $9.56 \pm 0.96$ & $5.62 \pm 0.91$ & $11.67 \pm 0.00$ & $9.01 \pm 0.00$ & $4.11 \pm 2.68$ & 250 \\
\hline Carbonate $(\mathrm{mg} / \mathrm{L})$ & $3.23 \pm 0.73$ & $3.46 \pm 0.45$ & $3.60 \pm 1.06$ & $3.94 \pm 0.36$ & $2.45 \pm 0.38$ & 100 \\
\hline Bicarbonate(mg/L) & $18.25 \pm 2.58$ & $22.81 \pm 1.31$ & $17.98 \pm 2.37$ & $23.09 \pm 5.84$ & $15.72 \pm 1.93$ & 100 \\
\hline Sulphate $(\mathrm{mg} / \mathrm{L})$ & $12.3 \pm 1.93$ & $13.9 \pm 1.93$ & $11.4 \pm 0.69$ & $14.9 \pm 1.67$ & $8.67 \pm 1.77$ & 3.0 \\
\hline
\end{tabular}

The $\mathrm{pH}$ of all harvested water sample ranged from 8.03 -9.17 with mean of 8.7. The mean value was above the WHO (2011) permissible range of 6.5- 8.5. The results showed that roof harvested rainwater samples from the area was slightly basic. Aluminum sheet recorded the maximum value while painted pan recorded the least. This might be due to atmospheric influence which usually results from anthropogenic activities since the control was also very basic (8.53). High carbonate, bicarbonate and hydroxide might probably be responsible for the high hydroxide potential. The high $\mathrm{pH}$ value from this study was similar to values obtained in Anambra State (Chukwuma et al., 2014) for harvested rainwater, although Udemesue (2015) reported harvested rainwater with $\mathrm{pH}$ less than the recommended limit of $6.5-8.5$. This implies that the role of rooftops among other factors influences the physicochemical characteristics of harvested rainwater in a particular environment.

Turbidity values ranged from $0.47-3.17$ NTU with the mean value of 1.2. This mean value was lower in comparison to the WHO limit of 5.0 NTU. High turbidity reflects the presence of particulate matter in the atmospheric air that is highly influenced by anthropogenic activities such as mining. Low turbidity values recorded in this study might be due to the fact that the harvested water were sampled from rural communities with minimal or low mining activities or other major particulate producing anthropogenic activities (Ovrawah and Hymone, 2001). 
The conductivities of the harvested rainwater were generally low with values ranging from $56.20-170.43$ $\mu \mathrm{s} / \mathrm{cm}$ with a mean value of $103.5 \mu \mathrm{s} / \mathrm{cm}$. This value was lower when compared with permissible level of $1000 \mu \mathrm{s} / \mathrm{cm}$. Total dissolved solids (TDS) concentrations ranged from $30.2-50.53 \mathrm{mg} / \mathrm{L}$ having a mean of $37.7 \mathrm{mg} / \mathrm{L}$. Coated pan recorded highest electrical conductivity and total dissolved solid, while Galvanized zinc recorded the lowest. These values were very low compared to the control and recommended value $(500 \mathrm{mg} / \mathrm{L})$ by WHO (2011) for drinking water. This is an indication that the harvested water samples were good and could be used as potable water. The study showed that coated rooftop has the tendency to increase EC and TDS of water. Vasudevan (2006) and WHO (2006) reported that rainwater quality is a function of rooftop among other factors.

Alkalinity and total hardness had respective values which ranged from $18.56-27.58 \mathrm{mg} / \mathrm{L}$ and $19.94-$ $24.08 \mathrm{mg} / \mathrm{L}$ with the mean of $24.19 \mathrm{mg} / \mathrm{L}$ and 21.80 $\mathrm{mg} / \mathrm{L}$ respectively. Alkalinity and total hardness of the rainwater samples were below the WHO permissible limit of $100 \mathrm{mg} / \mathrm{L}$ and $200 \mathrm{mg} / \mathrm{L}$ for drinkable water. Coated pan also recorded the highest for alkalinity and total hardness probably as a result of the inbuilt materials.
Sulphate and chloride ranged from $8.67-14.93 \mathrm{mg} / \mathrm{L}$ and $4.11-11.67 \mathrm{mg} / \mathrm{L}$ with mean values of 13.4 and 9 $\mathrm{mg} / \mathrm{L}$ respectively. The values were lowered compared with WHO (2011) permissible limit of 3.0 and 250 $\mathrm{mg} / \mathrm{L}$ respectively. Galvanized zinc recorded highest chloride concentration probably due to the components of this rooftop material or prevailing environmental factor in the catchment area (Neal and Kirchner, 2000). Concentration of carbonate, bicarbonate and sulphate were highest in coated pan though lowered than the control and recommended limits.

The levels of heavy metals in harvested rainwater also showed that the concentration ranged from $0-4.62$ $\mathrm{mg} / \mathrm{L}(\mathrm{Zn})$ with the mean of $2.82 \mathrm{mg} / \mathrm{L} ; 0.1-0.29$ $\mathrm{mg} / \mathrm{L}(\mathrm{Fe})$ with the mean of $0.05 \mathrm{mg} / \mathrm{L} ; 7.11-11.13$ $\mathrm{mg} / \mathrm{L}(\mathrm{Ca})$ with the mean of $10.27 \mathrm{mg} / \mathrm{L} ; 29.04-40.35$ $\mathrm{mg} / \mathrm{L}(\mathrm{Na})$ with the mean of $36.5 \mathrm{mg} / \mathrm{L}$; lead (not detected) and $0.01-0.02 \mathrm{mg} / \mathrm{L}(\mathrm{Cu})$ with the mean of $0.015 \mathrm{mg} / \mathrm{L}$ respectively. These mean values are however lowered compared with the WHO (2011) recommended limits for potable water with limits of $5.0 \mathrm{mg} / \mathrm{L}$ (Zinc), $0.3 \mathrm{mg} / \mathrm{L}$ (Iron), $75 \mathrm{mg} / \mathrm{L}$ (Calcium), $200 \mathrm{mg} / \mathrm{L}$ (Sodium), $0.01 \mathrm{mg} / \mathrm{L}$ (Lead), $1.0 \mathrm{mg} / \mathrm{L}$ (Copper), $30 \mathrm{mg} / \mathrm{L}$ and $\mathrm{mg} / \mathrm{L}$ respectively. Magnesium and Aluminum concentration were higher than the recommended limit of $0.3 \mathrm{mg} / \mathrm{L}$ and $0.05-0.2$ $\mathrm{mg} / \mathrm{L}$ (WHO, 2011) respectively.

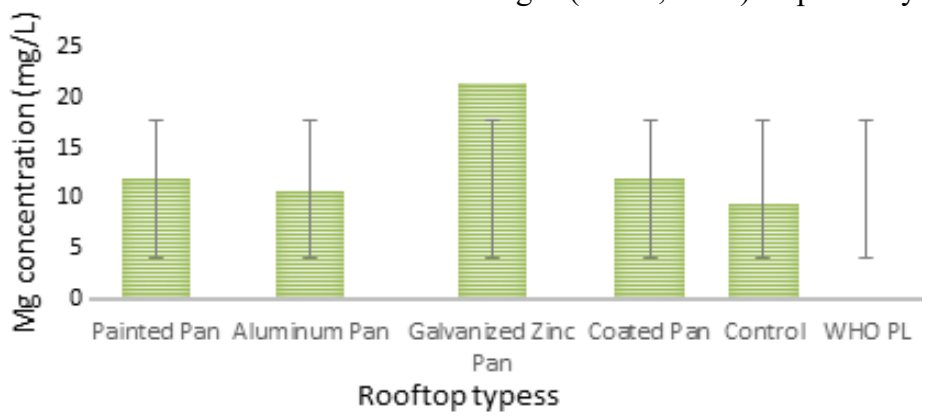

Fig 2: Magnesium concentrations of the rooftops rainwater samples

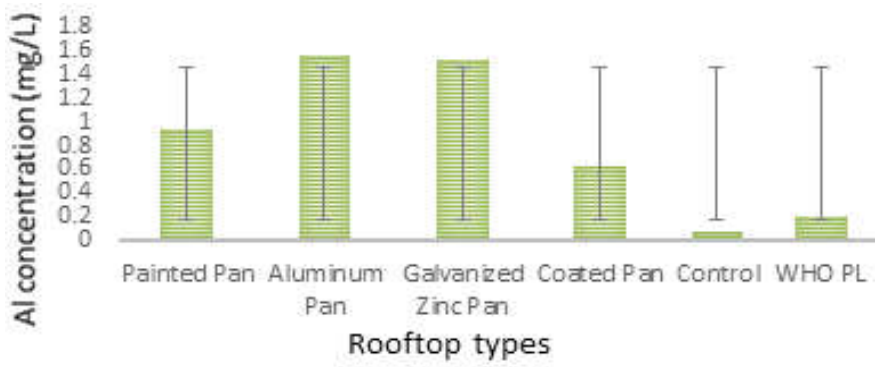

Fig 3: Aluminum concentrations of the rooftops rainwater samples

The mean values ranged from $9.41-21.33 \mathrm{mg} / \mathrm{L}(\mathrm{Mg})$ and $0.63-1.56 \mathrm{mg} / \mathrm{L}(\mathrm{Al})$ with average of $13.96 \mathrm{mg} / \mathrm{L}$ and $1.16 \mathrm{mg} / \mathrm{L}$. Galvanized zinc rooftop recorded the highest, while Aluminum rooftop recorded the least. 
Magnesium concentration was high in all the rooftops and in the control above the recommended limit $(0.3$ $\mathrm{mg})$. Results showed that all the roofing materials contributed to higher concentration of magnesium in the rainwater samples (Fig. 2). High concentration of magnesium has been associated with neurologic disorder (Anna et al., 2018), showing the urgent need to pay close attention to roofing types for water harvesting and manufacturer's adherence to standards. For aluminum, aluminum rooftop recorded highest concentration while coated rooftop recorded minimum (Fig. 3). Thus, the study showed possible contamination from these rooftop components most especially aluminum and galvanized rooftops.

Temijenovic (2011) reported that Aluminum (Al) is the most abundant neuro-toxic metal on earth, widely bio-available to humans and repeatedly shown to accumulate in AD-susceptible neuronal foci. One of the pathways to human ingestion is through water and it is responsible for Alzheimer's disease. Alzheimer's disease cause by aluminum is the most prevalent neurodegenerative disease of the elderly and is characterized by regional specificity of neural aberrations associated with higher cognitive functions Higher concentrations of this metal in aluminum rooftop may constitute a potential source of danger to human health. Zinc is an essential element, yet it gives undesirable astringent taste to water at levels above the standard limit $(5.0 \mathrm{mg} / \mathrm{L})$. The low level of Zinc in the analyzed rainwater was probably due to the zero industrial and motor vehicular activities in the study area.

Water Quality Index: Water Quality Index provides a numerical value that represents overall water quality usually at a given location and time, based on several water parameters (Chaterjee and Raziuddin, 2002 and Thakor et al., 2011) as indicated in Table II.

Table 2: Water Quality Index (WQI) and Corresponding Water

\begin{tabular}{lll}
\multicolumn{2}{c}{ Quality Status } \\
\hline S/N & WQI & Status \\
\hline 1 & $0-25$ & Excellent Water Quality \\
2 & $26-50$ & Good Water Quality \\
3 & $51-75$ & Poor Water Quality \\
4 & $76-100$ & Very Poor Water Quality \\
5 & $>100$ & Unsuitable \\
\hline
\end{tabular}

The WQI for the rainwater harvested samples was established from various physicochemical parameters for the different rooftops (Painted Pan rooftop, Aluminum rooftop, Galvanized zinc rooftop and coated pan rooftops). The WQI values of the various physicochemical parameters for the different rooftops were 3.30, 1.34, 6.08 and 2.63 for Painted Pan rooftop, Aluminum rooftop, Galvanized zinc rooftop and coated pan rooftop respectively. The computed WQI ranged from $1.34-3.27$ for the different rooftops which indicates that the harvested rainwater quality is excellent as it falls within the $0-25$ range of overall water quality standard.

Conclusion: Physicochemical characteristics of the rainwater samples collected from four different rooftops were all within the acceptable standard except for $\mathrm{pH}$, aluminium (aluminium rooftop) and magnesium (Coated rooftop) concentrations which were slightly basic and higher than the permissible limits for drinking water. Observed was that there was no pattern of water quality variation in the selected roof types. Moreover, though the overall water quality as indicated by Water Quality Index showed acceptable quality, minimum treatment is suggested to make the water suitable for drinking purposes. It is however recommended that the harvested rainwater be further treated appropriately before drinking. This will help complement or improve the water quality thereby providing portable water for households in the communities.

\section{REFERENCES}

Anna, E; Kirkland, GLS; Kathleen FH (2018). The Role of Magnesium in Neurological Disorders, Nutrients, 10(6): 730.

Ayenimo, JG; Adekunle, AS; Makinde,WO; Ogunlusi., GO (2006). Heavy metal-fractionation in roof run off in Ile-Ife, Nigeria. Inter. J. Environ. Sci. Technol. 3 (3): 221-227.

APHA (1999). Standard Methods for the Examination of Water and Wastewater: For the Examination of Water and Wastewater, APHA, AWWA, WEF/1995, APHA Publication.

Bayowa OG; Olorunfemi MO; Akinluyi FO; and Ademilua OL (2014). A Preliminary Assessment of the Groundwater Potential of Ekiti State, Southwestern Nigeria, using Terrain and Satellite Imagery Analyses. J. Environ. Earth Sci. 4(3): 4885.

Chaterjee, C; Raziuddin, M (2002). Determination of water quality index (WQI) of a degraded river in Asanol Industrial area, Raniganj, Burdwan, West Bengal. Nature Environ. Poll. Technol. 2:181189.

Chukwuma, JN; Nnodu, VC; Okoye, AC; Chukwuma, EC (2014). Assessment of Roof Harvested Rainwater in Parts of Anambra State for 
Environmental Pollution Monitoring. British Biotech. J., 4(10): 1105-1114

Neal, C; Kirchner, JW (2000). Sodium and chloride levels in rainfall, mist, stream water and groundwater at the Plynlim on catchments, mid Wales: inferences on hydrological and chemical controls, Hydro. Earth Syst. Sci., 4(2):29-310

Temijenovic, L (2011). Aluminium and Alzheimer's disease: after a century of controversy, is there a plausible link, J. Alzheimer's Dis, 23(4):567-98. doi: 10.3233/JAD-2010-101494.

Talabi, OA (2013). Mineralogical and chemical characterization of major basement rocks in Ekiti State, SW-Nigeria. $R M Z-M \& G$., 60:73-86.

Thakor, FJ; Bhoi, DK; Dabhi, HR; Pandya, SN; Chauhan, NB (2011). Water Quality Index (WQI) of Pariyej Lake District Kheda, Gujarat. Current World Environ. 6: 225-231.

Oladapo, MI; Ayeni, OG (2013). Hydrogeophysical Investigation in Selected Parts of Irepodun/Ifelodun Local Government Area of Ekiti State, Southwestern Nigeria J. Geol. Min. Res. 5(7): $200-207$.

Oyinloye, AO (2007): Geology and Geochemistry of some Crystalline Basement Rocks in Ilesha area southwestern Nigeria: Implications on Provenance and Evolution Pak. J. Sci. Ind. Res. 50(4): 223-231.

Ovrawah, L; Hymone, F. K. (2001). Quality of water from hand-dug well in the Warri environs of Niger Delta. Afri. J. Environ. Stud. 2 (2): 169-170.

Qureshimatva, UM; Maurya, RR; Gamit, SB; Patel, RD; Solanki, HA (2015). Determination of Physicochemical Parameters and Water Quality Index (WQI) of Chandlodia Lake, Ahmedabad, Gujarat, India. J. Environ. Anal Toxic 5:4
Retamal, M; Turner, A (2010). Unpacking the energy implications of distributed water infrastructure: how are rainwater systems performing? Water Sci. Technol. Water Supply, 10(4):546-553.

Udemesue, CE (2012). Quality of Rainwater Harvested in Cisterns in Onicha-Ugbo, AniochaNorth Local Government Area of Delta State, Nigeria. A Dissertation Submitted to the School of Postgraduate Studies, Ahmadu Bello University, Zaria in Partial Fulfillment of the Requirements for the Award of Master of Science (Msc) Degree in Environmental Management.

Ukpong, EC; Ogarekpe, NM; and Bejor, ES (2013). Comparative Analysis of Water Quality in Hand Dug Well and Borehole in Calabar South Local Government Area in Nigeria. Inter. J. Engineer. Sci. 2(8): 95-101.

Vasudevan, L (2006). A study of biological contaminants in rainwater collected from rooftops in Bryan and College Station, Texas. Master's thesis, Texas A \&M University, College Station, Texas.

World Health Organization (WHO) (2011). Guidelines for Drinking-Water Quality, WHO Press, Geneva, Switzerland, 4th edition.

World Health Organization (2006): Health risks of particulate matter from long-range transboundary air pollution. European Centre for Environment and Health Bonn Office, pp 1- 113.

WHO (2006). Guidelines for Drinking Water Quality. First addendum to Vol 1: Recommendations, 3rd edition, WHO, Geneva. 